International Journal of Current Advanced Research

ISSN: O: 2319-6475, ISSN: P: 2319 - 6505, Impact Factor: SJIF: 5.995

Available Online at www.journalijcar.org

Volume 6; Issue 4; April 2017; Page No. 3122-3123

DOI: http://dx.doi.org/10.24327/ijcar.2017.3123.0199

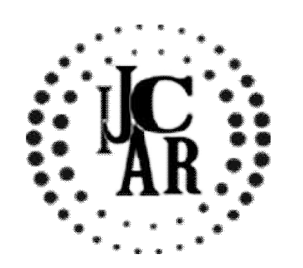

Research Article

\title{
EFFECT OF ROSEMARY OIL EXTRACT ON BIOFILM FORMATION BY STREPTOCOCCUS MUTANS-A INVITRO STUDY
}

\author{
Sarvesh Kumar J and Geetha
}

Saveetha Dental College and Hospitals, 162, P.H Road, Chennai, Tamilnadu 600077

\begin{tabular}{l}
\hline A R T I C L E I N F O \\
Article History: \\
Received $13^{\text {th }}$ January, 2017 \\
Received in revised form $19^{\text {th }}$ February, 2017 \\
Accepted $22^{\text {nd }}$ March, 2017 \\
Published online $28^{\text {th }}$ April, 2017
\end{tabular}

\section{Key words:}

Rosemary oil, biofilm, Streptococcus mutans.

\begin{abstract}
A B S T R A C T
Aim: To identify the effects of rosemary oil extract on biofilm formation by Streptococcus mutans.

Background: A biofilm is any group of microorganisms in which cells stick to each other and often these cells adhere to a surface. These adherent cells are frequently embedded within a self produced matrix of extracellular polymeric substance (EPS). Streptococcus mutans is implicated as a major etiological agent in human dental caries, and one of the important virulence properties of this organism is its ability to form biofilms ( dental plaque) on tooth surfaces. The present study was done to identify the effects of rosemary oil on biofilm formation by Streptococcus mutants.

Materials and Methods: The organism Streptococcus mutans was isolated from saliva sample using special media [Mutans - sanguis agar] and maintained in Tryptose soya agar at 4 degree $C$ in department of microbiology, Saveetha dental college and hospitals.

Results: On analyzing the results it was observed that rosemary oil tends to prevent biofilm formation by Streptococcus mutans

Conclusion: Rosemary oil can be effectively used in dental aids to prevent biofilm formation
\end{abstract}

Copyright $₫ 2017$ Sarvesh Kumar J and Geetha. This is an open access article distributed under the Creative Commons Attribution License, which permits unrestricted use, distribution, and reproduction in any medium, provided the original work is properly cited.

\section{INTRODUCTION}

A biofilm is any group of microorganisms in which cells stick to each other and often these cells adhere to a surface. ${ }^{[1]}$ These adherent cells are frequently embedded within a self produced matrix of extracellular polymeric substance (EPS). ${ }^{[2]}$ Streptococcus mutans. is implicated as a major etiological agent in human dental caries, and one of the important virulence properties of this organism is its ability to form biofilms (dental plaque) on tooth surfaces. ${ }^{[3]}$ The cells that attach irreversibly to surfaces (i.e., those not removed by gentle rinsing) will begin cell division, form microcolonies, and produce the extracellular polymers that define a biofilm. ${ }^{[4]}$ These extracellular polymeric substances (EPSs) consist primarily of polysaccharides and can be detected microscopically and by chemical analysis. EPSs provide the matrix or structure for the biofilm. ${ }^{[5]}$ They are highly hydrated (98\% water) and tenaciously bound to the underlying surface. The structure of the biofilm is not a mere homogeneous monolayer of slime but is heterogeneous, both in space and over time, with "water channels" that allow transport of essential nutrients and oxygen to the cells growing within the biofilm. ${ }^{[6]}$ Presence of biofilm leads to dental problems like plaque and gingivitis which are the root cause of dental caries. $^{[7]}$

\section{*Corresponding author: Sarvesh Kumar J}

Saveetha Dental College and Hospitals, 162, P.H Road, Chennai, Tamilnadu 600077
Dental plaque is an oral biofilm that adheres to the teeth and consists of many species of both bacteria and fungi (such as Streptococcus mutans and Candida albicans), embedded in salivary polymers and microbial extracellular products. The accumulation of microorganisms subjects the teeth and gingival tissues to high concentrations of bacterial metabolites which results in dental caries. ${ }^{[8]}$ Rosemary (Rosmarinus officinalis) oil is one of the most popular essential oils for its wide array of health benefits. ${ }^{[9]}$ It has become increasingly important and popular over the years as more of its various health benefits. The present study was done to identify the effects of rosemary oil on biofilm formation by Streptococcus mutants.

\section{METHODS}

Overnight grown cultures of Streptococcus mutants from agar plates were inoculated in Tryptose Soy broth and incubated at 37 degree Celsius overnight. Individual wells of sterile polystyrene 96 well flat bottom micro titre plates were filled with $200 \mu \mathrm{l}$ of culture suspension of the test organism. Uninoculated broth served as negative control. To the wells containing bacterial suspension 10 micro litres of the rosemary oil was added from the prepared stock solution of 10,20,40,80 and $100 \mu \mathrm{g} / \mathrm{ml}$ respectively and incubated at 37 degree $\mathrm{C}$ for 24 hours. After incubation, content in the wells were removed, washed with $0.2 \mathrm{ml}$ phosphate buffer saline to 
remove free floating bacteria. The adherence of the bacteria were fixed with sodium acetate $(2 \%)$ and stained with crystal violet. The crystal violet was removed and 250 micro litre of acetone was placed in each well to release the crystal violet. Then finally the readings were taken. Optical density of stained adherent bacteria was determined with an ELISA reader (Bio-Rad) at wavelength $570 \mathrm{~nm}$. These OD values were taken as index of bacteria adhering the surface and formed biofilm. Experiment was carried out in triplicate and their mean was taken for the analysis

\begin{tabular}{ccc}
\hline $\begin{array}{c}\text { Mean od } \\
\text { values }\end{array}$ & Adherence & $\begin{array}{c}\text { Biofilm } \\
\text { formation }\end{array}$ \\
\hline$<0.120$ & Non & Non/weak \\
$0.120-0.240$ & Moderately & Moderate \\
$>0.240$ & Strong & High \\
\hline
\end{tabular}

The above mentioned interpretation charge was applied to categorize the ability of S.mutans to form biofilm.

\section{RESULTS AND DISCUSSION}

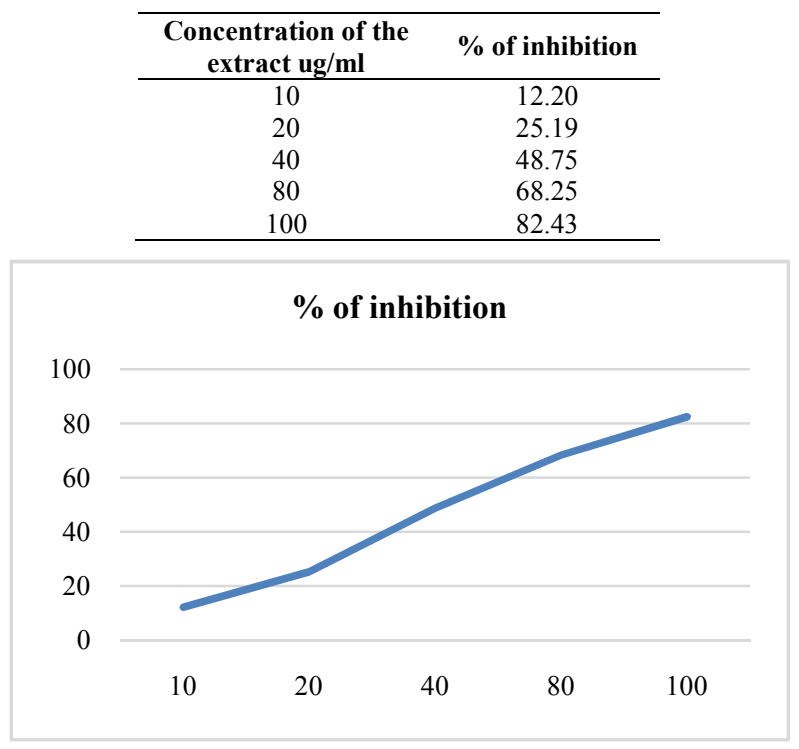

Graph 1 Percentage of inhibition of Rosemary oil on Streptococcus mutans

Dental caries is a disease which is nowadays most commonly seen among children and adolescents and has been found that regular brushing and use of mouthwash tends to reduce the incidence of caries in a very effective way among which the effects of rosemary oil in preventing biofilm formation by Streptococcus mutans had been more convincing. In the present study it is observed that $10 \mathrm{ug} / \mathrm{ml}$ of rosemary oil inhibits biofilm formation by $12.20 \%, 20 \mathrm{ug} / \mathrm{ml}$ shows $25.19 \%$ inhibition, $40 \mathrm{ug} / \mathrm{ml}$ shows $48.75 \%$ inhibition, 80 $\mathrm{ug} / \mathrm{ml}$ shows $68.25 \%$ inhibition and $100 \mathrm{ug} / \mathrm{ml}$ shows $82.43 \%$ inhibition, these values clearly indicates that as the concentration of rosemary oil increases it more potentially inhibits the biofilm formation by Streptococcus mutans

\section{CONCLUSION}

Rosemary essential oil is a disinfectant. It also helps in removing bad breath. By removing oral bacteria, rosemary essential oil can prevent gingivitis, cavities, plaque build up, and other damaging dental conditions. So it can be used in dental aids like mouthwash and tooth paste as an alternative for chemicals, as these chemicals in long term can cause side effects like erosion of enamel etc.

\section{References}

1. Baheerati; Natural Ingredients against Biofilm Formation J. Pharm. Sci. \& Res. Vol. 8(10), 2016, 1237-1239

2. Dufour, Delphine, Vincent Leung, and Céline $M$. Lévesque. "Bacterial biofilm: structure, function, and antimicrobial resistance." Endodontic Topics 22.1 (2010): 2-16. Web.

3. Jeffrey, A. Banas. "Virulence properties of Streptococcus Mutans." Frontiers in Bioscience 9.1-3 (2004): 1267. Web.

4. Devaraj, Sharmila, Nithya Jagannathan, and Prasanna Neelakantan. "Antibiofilm efficacy of photoactivated curcumin, triple and double antibiotic paste, 2\% chlorhexidine and calcium hydroxide against Enterococcus fecalis in vitro." Scientific Reports 6 (2016): 24797. Web.

5. Donlan, Rodney M. "Biofilm Formation: A Clinically Relevant Microbiological Process." Clinical Infectious Diseases 33.8 (2001): 1387-392. Web.

6. Lewandowski Z. Evans LV. Structure and function of biofilms, Biofilms: recent advances in their study and control,2000 Amsterdam Harwood Academic Publishers (pg. 1-17)

7. Nazia Zareen; Gopinath Prakasam; oral biofilms; Research Journal of Pharmacy and Technology; ISSN: 0974-360X(Online),

8. Augustin Mihai; Carmen Balotescu-Chifiriuc; Veronica Lazăr; Ruxandra Stănescu; Mihai Burlibașa; Dana Catrinel Ispas (Dec 2010). "Microbial biofilms in dental medicine in reference to implanto-prostethic rehabilitation". 1 (1): 9-13. ISSN 2069-3850

9. Bozin, Biljana, Neda Mimica-Dukic, Isidora Samojlik, and Emilija Jovin. "Antimicrobial and Antioxidant Properties of Rosemary and Sage (Rosmarinus officinalis L. and Salvia officinalis L., Lamiaceae) Essential Oils." Journal of Agricultural and Food Chemistry 55.19 (2007): 7879-885. Web.

\section{How to cite this article:}

Sarvesh Kumar J and Geetha (2017) ' Effect Of Rosemary Oil Extract On Biofilm Formation Bystreptococcus Mutans-A Invitro Study', International Journal of Current Advanced Research, 06(04), pp. 3122-3123.

DOI: http://dx.doi.org/10.24327/ijcar.2017.3123.0199 